\title{
Effective bioremediation strategy for rapid in situ cleanup of anoxic marine sediments in mesocosm oil spill simulation
}

\author{
Maria Genovese ${ }^{1+}$, Francesca Crisafi ${ }^{1+}$, Renata Denaro ${ }^{1}$, Simone Cappello ${ }^{1}$, Daniela Russo ${ }^{1,2}$, \\ Rosario Calogero ${ }^{1}$, Santina Santisi ${ }^{1,2}$, Maurizio Catalfamo ${ }^{1}$, Alfonso Modica ${ }^{3}$, Francesco Smedile ${ }^{1}$, \\ Lucrezia Genovese $^{1}$, Peter N. Golyshin ${ }^{4}$, Laura Giuliano ${ }^{1,5}$ and Michail M. Yakimov ${ }^{1 *}$ \\ 1 Institute for Coastal Marine Environment, CNR, Messina, Italy \\ ${ }^{2}$ Department of Biological and Environmental Sciences, University of Messina, Messina, Italy \\ ${ }^{3}$ Environmental Laboratory, Syndial SpA, Priolo Gargallo, Italy \\ ${ }^{4}$ Environmental Genomics, School of Biological Sciences, Bangor University, Bangor, UK \\ ${ }^{5}$ Mediterranean Science Commission, Monaco, Monaco
}

\section{Edited by:}

Ian M. Head, Newcastle University, UK

\section{Reviewed by:}

Kathleen Scott, University of South

Florida, USA

Anne Bernhard, Connecticut

College, USA

${ }^{*}$ Correspondence:

Michail M. Yakimov, Institute for Coastal Marine Environment, CNR, Spianata S. Raineri, 86,

98122 Messina, Italy

e-mail: michail.yakimov@iamc.cnr.it

these authors have contributed equally to this work.
The purpose of present study was the simulation of an oil spill accompanied by burial of significant amount of petroleum hydrocarbons (PHs) in coastal sediments. Approximately $1000 \mathrm{~kg}$ of sediments collected in Messina harbor were spiked with Bunker C furnace fuel oil $(6500 \mathrm{ppm})$. The rapid consumption of oxygen by aerobic heterotrophs created highly reduced conditions in the sediments with subsequent recession of biodegradation rates. As follows, after 3 months of ageing, the anaerobic sediments did not exhibit any significant levels of biodegradation and more than $80 \%$ of added Bunker $\mathrm{C}$ fuel oil remained buried. Anaerobic microbial community exhibited a strong enrichment in sulfate-reducing PHs-degrading and PHs-associated Deltaproteobacteria. As an effective bioremediation strategy to clean up these contaminated sediments, we applied a Modular Slurry System (MSS) allowing the containment of sediments and their physical-chemical treatment, e.g., aeration. Aeration for 3 months has increased the removal of main $\mathrm{PHs}$ contaminants up to $98 \%$. As revealed by CARD-FISH, qPCR, and 16S rRNA gene clone library analyses, addition of Bunker $\mathrm{C}$ fuel oil initially affected the activity of autochthonous aerobic obligate marine hydrocarbonoclastic bacteria (OMHCB), and after 1 month more than the third of microbial population was represented by Alcanivorax-, Cycloclasticus-, and Marinobacter-related organisms. In the end of the experiment, the microbial community composition has returned to a status typically observed in pristine marine ecosystems with no detectable OMHCB present. Eco-toxicological bioassay revealed that the toxicity of sediments after treatment was substantially decreased. Thus, our studies demonstrated that petroleum-contaminated anaerobic marine sediments could efficiently be cleaned through an in situ oxygenation which stimulates their self-cleaning potential due to reawakening of allochtonous aerobic OMHCB.

Keywords: marine anoxic sediments, crude oil pollution, hydrocarbonoclastic bacteria, in situ bioremediation, aerated slurry system

\section{INTRODUCTION}

The worldwide production of crude oil and natural gas is at the peak, with an estimated worldwide production of 89 million barrels per day in 2011 (International Energy Agency, http:// omrpublic.iea.org/). Approximately, a half of this amount is transported by the sea (Gertler et al., 2010). As follows, worldwide marine coastal areas are exposed to the oil spills occurring as a result of accidents or illegal practices (Psarros et al., 2010). The release of thousands of tons of petroleum hydrocarbons (PHs) affects the marine environment and causes severe ecological and economical damage. For example, only the pollution resulting from the tanker washing or ballast water has been estimated to contribute about 2 million tons per year worldwide (Ferraro et al., 2007; Gertler et al., 2010). The recent spillage of $780,000 \mathrm{~m}^{3}$ of oil into the Gulf of Mexico proved again that human activities might cause a contamination without precedents. This accident presented a huge challenge to existing oil spill treatment methods, and current technologies were not able to cope with the size and nature of the Deepwater Horizon oil spill. Therefore, there is an urgent demand for development and optimization of bioremediation techniques that can play a central role in marine oil spill response contingency plans.

One of the most important issues in bioremediation is the application (or stimulation) of autochthonous hydrocarbondegrading microbial populations. Some marine gammaproteobacteria have a high affinity toward PHs. Species such as Alcanivorax borkumensis (Yakimov et al., 1998), Cycloclasticus pugetii (Dyksterhouse et al., 1995), Oleispira antarctica (Yakimov 
et al., 2003), Oleiphilus messinensis (Golyshin et al., 2002), and Thalassolituus oleivorans (Yakimov et al., 2004) constitute a distinct group of obligate marine hydrocarbon-degrading bacteria (OMHCB). Following a sudden oil spill event, these organisms outcompete most of the naturally occurring oligotrophic marine microorganisms (Hara et al., 2003; Yakimov et al., 2007). Growing on PHs, aerobic OMHCB use oxygen not only as the terminal electron acceptor for respiratory energy conservation, but also as an indispensable reactant in the PHs activation mechanism. Thus, the stimulation of the OMHCBs degradation activity in the contaminated site can significantly improve the self-cleaning potential. Unfortunately, due to metabolic requirements of the OMHCBs, this type of bioremediation is restricted to either seawater column or superficial sediments. Due to a high biological oxygen demand and its slow diffusion into marine sediments, these compartments below the surface are typically highly reduced (Engelen and Cypionka, 2009). The realization that activated oxygen is used to overcome the chemical sluggishness of hydrocarbons has for some decades favored the view that hydrocarbons are not biodegradable under anoxic conditions (Widdel and Rabus, 2001). Although recently, a number of strictly anaerobic microorganisms have been shown to utilize PHs as growth substrates, this process is extremely slow compared to aerobic degradation and can not be considered as rapid bioremediation scenario.

The aim of this study was to monitor both immediate and long-term responses of indigenous microbial consortia to a simulated oil spill and during bioremediation treatment. Keeping in mind that the decontamination of PHs-polluted anoxic sediments is a very sluggish process, the stimulation of indigenous aerobic OMHCBs was performed by the in situ aeration of sediments within a modular slurry system (MSS) to avoid the contamination of the surrounding aquifer. The succession of microbial community and efficacy of petroleum biodegradation in both untreated (anoxic) external and aerated internal sediments was monitored during 3 months after contamination. Additionally, the toxicity of sediments was controlled by application of Microtox ${ }^{\circledR}$ and amphipods Corophium orientale eco-toxicological bioassays.

\section{MATERIALS AND METHODS EXPERIMENTAL MESOCOSM}

The experiment was carried out in rectangular tank of $3.75 \mathrm{~m}^{3}$ capacity ( $166 \mathrm{~cm}$ long, $150 \mathrm{~cm}$ deep, $150 \mathrm{~cm}$ wide). This reservoir was filled with ca. $2000 \mathrm{l}$ of seawater taken directly from the harbor of Messina ( $\left.38^{\circ} 11^{\prime} 42.58^{\prime \prime} \mathrm{N} 15^{\circ} 34^{\prime} 25.19^{\prime \prime} \mathrm{E}\right)$. Prior to use, the seawater was filtered through a $200 \mu \mathrm{m}$ nylon mesh to remove large metazoans and detritus. Approximately $1000 \mathrm{~kg}$ of sandy sediments were collected at the same place and artificially contaminated with Bunker C furnace fuel oil (6500 ppm) to simulate the oil spill accident. Temperature inside the mesocosm was maintained about $20 \pm 1^{\circ} \mathrm{C}$ for all experimental period. Mesocosm has continuously received seawater at the flow rate of $11 \mathrm{~min}^{-1}$. The MSS used in mesocosm experiment is shown on Figure 1. The MSS was developed especially for in situ aeration $\left(201 \mathrm{~min}^{-1}\right)$ of polluted sediments without their removal from contaminated side to avoid the re-contamination of adjacent aquifer. The reactor was inserted into the sediment. Sediment directly beneath the MSS were treated by the reactor, and those sediments outside of it were undisturbed and served as a control. All experimentations have been conducted for 3 months. To monitor the succession of microbial population and the efficiency of petroleum degradation, $1.5-2.0 \mathrm{~kg}$ of sediments (up to $10 \mathrm{~kg}$ in total) were sampled on fixed days $\left(\mathrm{T}_{0}, \mathrm{~T}_{1}, \mathrm{~T}_{29}\right.$, and $\left.\mathrm{T}_{90}\right)$ at six different points inside and outside the MSS. Additionally, measurements of the biochemical oxygen demand $\left(\mathrm{BOD}_{5}\right)$, reduction potential $\left(\mathrm{E}_{\mathrm{h}}\right)$, and eco-toxicological assays (Microtox ${ }^{\circledR}$ and Corophium orientale mortality test) were monitored. The $\mathrm{E}_{\mathrm{h}}$ of sediment was measured by a Waterproof CyberScan PCD 650
A

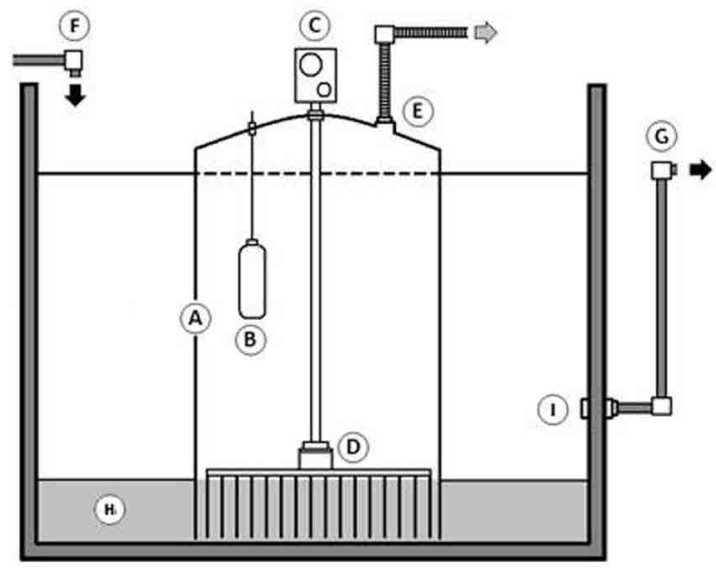

B

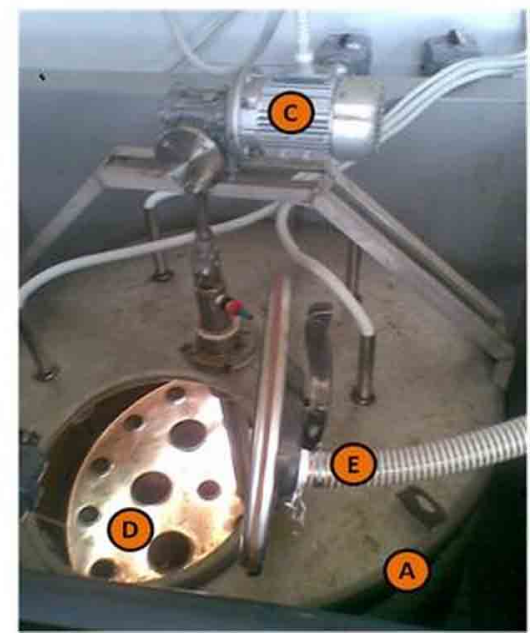

FIGURE 1 | (A,B) Schematic representation (A) and detail (B) of "Modular Slurry System" used throughout this study. Abbreviation used: $A$, Modular Slurry System; B, temperature controller; C, external air pump;
$D$, steel plate with needles to supply an oxygen into deep sediments: $E$ exhaust tube; $F$, seawater inlet; $G$, seawater outlet; $H$, contaminated sediments; I, overflow regulation system. 
multiparameter (Eutech Instruments) according to the manufacturer's instructions at aforementioned time intervals. $\mathrm{BOD}_{5}$ was measured using a BOD sensor (VELP Scientifica) after 5 days of incubation in accordance with the manufacturer's instructions.

\section{ANALYSIS OF PETROLEUM HYDROCARBONS}

Efficiency of petroleum degradation was estimated by the analysis of total extracted and resolved hydrocarbons (TERHC). At the fixed time points, TERCH were extracted from sediments following the 3550C EPA (Environmental Protection Agency) procedure. Briefly, $500 \mathrm{ml}$ mixture of $\mathrm{CH}_{2} \mathrm{Cl}_{2}: \mathrm{CH}_{3} \mathrm{COCH}_{3}$ (1: 1, $\mathrm{vol} / \mathrm{vol}$ ) was added to $1000 \mathrm{~g}$ of pooled and dried either internal or external sediments, collected from six different sites (see above). Mixture was sonicated for $2 \mathrm{~min}$ in ultrasound bath (Branson 1200 Ultrasonic Cleaner, Branson USA). Samples were further shaken at $150 \mathrm{rpm}$ for $30 \mathrm{~min}$, centrifuged for $10 \mathrm{~min}$ at $5000 \times \mathrm{g}$ and supernatant was passed through a ceramic column filled with anhydrous $\mathrm{Na}_{2} \mathrm{SO}_{4}$ (Sigma-Aldrich, Milan). Same treatment of pooled and dried sediments was repeated with $500 \mathrm{ml}$ of $\mathrm{CH}_{2} \mathrm{Cl}_{2}$ and the obtained extracts were combined and volatilized to the dryness. Residues were re-suspended in $\mathrm{CH}_{2} \mathrm{Cl}_{2}$ prior the gas chromatography (GC) analysis (Rocchetti et al., 2011). All measures were performed using a Master GC DANI Instruments (Development ANalytical Instruments), equipped with SSL injector and FID detector. Sample $(1 \mu \mathrm{l})$ was injected in splitless mode at $330^{\circ} \mathrm{C}$. The analytical column was a Restek Rxi-5 Sil MS with Integra-Guard, $30 \mathrm{~m} \times 0.25 \mathrm{~mm}$ (ID $\times 0.25 \mu \mathrm{m}$ film thickness). Helium carrier gas was maintained at a constant flow of $1.5 \mathrm{ml}$ $\mathrm{min}^{-1}$. TERCH were calculated using the mean response factors of $n$-alkanes, i.e., individual $n$-alkane concentrations from $n-\mathrm{C}_{15}$ to $n-\mathrm{C}_{40}$, pristane and phytane were calculated for each sample. To estimate the biodegradation of aliphatic fraction, the evaluation indices $n-\mathrm{C}_{17} /$ pristane and $n-\mathrm{C}_{18} /$ phytane were selected for this study. The amount of analyzed TERCH was expressed as ppm (part per million) or $\mathrm{mg} \mathrm{kg}^{-1}$.

\section{ECOTOXICOLOGICAL ASSAYS}

The Microtox ${ }^{\circledR}$ luminescence assay was performed on sediment pore water. Sub-samples of sediment were centrifuged $(5000 \times$ $\mathrm{g}$ for $\left.45 \mathrm{~min}, 4^{\circ} \mathrm{C}\right)$ and filtered $(0.45 \mu \mathrm{m}$ nitrate cellulose membrane) to remove the fine suspended particles and maintained at $4^{\circ} \mathrm{C}$ until used in assays. Microtox ${ }^{\circledR}$ toxicity tests were conducted according to the standard procedures EN12457 with the following modifications. As far as the Solid Phase Test deals with fine particles that affected the bioluminescence of bacteria (Bulich et al., 1992; Benton et al., 1995; Ringwood et al., 1997), each experimental sediment sample was compared with a reference sediment sample with the same granulometry, collected from a pristine site. Toxicities were reported as effective concentration of toxicant resulting in a $50 \%$ decrease in bioluminescence $\left(\mathrm{EC}_{50}\right) . \mathrm{EC}_{50}$ with $95 \%$ of confidence intervals were calculated following the procedures outlined in the Microtox ${ }^{\circledR}$ System Operating Manual (Microtox, 1982). Amphipods Corophium orientale were delivered from CIBM (Livorno, Italy). The animals were used following the procedure reported by Onorati et al. (1999). Briefly, the juveniles and young adults, which passed through $1000 \mu \mathrm{m}$ and retained by $710 \mu \mathrm{m}$ mesh sieve, were selected for ecotoxicology experiments. The test was carried out inside 2.5-l glass flasks containing approximately $2 \mathrm{~cm}$ layer of sediments and filled with $1000 \mathrm{ml}$ of filtered seawater. The seawater was aerated and kept at a constant temperature $\left(16 \pm 2^{\circ} \mathrm{C}\right)$. Flasks were illuminated during $12 \mathrm{~h}$ daily by a lamp system consisted of six tubes $(36 \mathrm{~W}$, $120 \mathrm{~cm}$ ). One hundred amphipods were randomly selected and introduced into each flask. No food was added to the test and control chambers. At the end of exposition (10 days), amount of survived organisms were counted. Missing amphipods were assumed as dead animals. The sensitivity of the populations was estimated as a fraction of dead organisms to the initial amount of added amphipods. All the experiments were replicated twice.

\section{TOTAL RNA EXTRACTION, REVERSE TRANSCRIPTION-PCR (RT-PCR) AND $16 S$ rRNA CLONE LIBRARIES}

Total RNA was extracted from sediment sample $(5 \mathrm{~g})$ using the FastRNA ${ }^{\circledR}$ Pro soil direct Kit (MP Biomedicals ${ }^{\mathrm{TM}}$ ) as previously described (Roussel et al., 2009). Extracted RNA from three different samples was pooled and further converted to cDNA using First-Strand cDNA Synthesis SuperScript ${ }^{\mathrm{TM}}$ II Reverse Transcriptase (Life Technologies). RT reaction mixtures $(20 \mu \mathrm{l})$ contained $1 \mu \mathrm{l}$ the random hexamer primer mix (Bioline), $30 \mathrm{ng}$ of RNA, $1 \mu \mathrm{l} 10 \mathrm{mM}$ dNTPs (Gibco, Invitrogen Co., Carlsbad, $\mathrm{CA})$ and sterile distilled water $(14 \mu \mathrm{l})$. After heating to $65^{\circ} \mathrm{C}$ for $5 \mathrm{~min}$, and incubate on ice for $1 \mathrm{~min}$, the mixture was supplemented with $4 \mu \mathrm{l}$ of $5 \times$ First-Strand Buffer, $1 \mu \mathrm{l}$ of DTT and $1 \mu l$ of SuperScript ${ }^{\mathrm{TM}}$. The mixture was shaken and incubated at $50^{\circ} \mathrm{C}$ for $30 \mathrm{~min}$. Finally, SuperScript ${ }^{\mathrm{TM}}$ enzyme was inactivated by heating at $70^{\circ} \mathrm{C}$ for $15 \mathrm{~min}$. $16 \mathrm{~S}$ rRNA genes were amplified from total cDNA using the universal primes (530F [5'-GTGCCAGCM GCCGCGG-3'] and 1492R [5'-TACGGYTACCTTGTTACGACT$\left.3^{\prime}\right]$ ) (Lane, 1991). The PCR was performed in $50 \mu l$ mixture (total volume) containing $1 \times$ solution $Q$ (Qiagen), $1 \times$ Qiagen reaction buffer, $1 \mu \mathrm{M}$ of each forward and reverse primer, $10 \mu \mathrm{M}$ dNTPs (Gibco, Invitrogen Co.), $2.0 \mathrm{ml}$ (50-100 ng) of template and 2.0 $\mathrm{U}$ of Qiagen Taq Polymerase (Qiagen). The reaction $\left(3 \mathrm{~min}\right.$ hot-start at $95^{\circ} \mathrm{C} ; 1 \mathrm{~min}$ at $94^{\circ} \mathrm{C}, 1 \mathrm{~min}$ at $50^{\circ} \mathrm{C}, 2 \mathrm{~min}$ at $72^{\circ} \mathrm{C}, 30$ cycles; final extension $10 \mathrm{~min}$ at $72^{\circ} \mathrm{C}$ ) was performed with GeneAmp 5700 (PE Applied Biosystems). The quality of amplification products was checked by agarose electrophoresis and purified using Qiaquick Gel Extraction kit (Qiagen). Purified $16 \mathrm{~S}$ crDNA amplicons were further cloned into the pGEM Teasy Vector II (Promega), transformed into E. coli DH10 $\beta$ cells and subsequently amplified with primers, specific for the pGEM T-easy vector (M13F (5'-TGTAAAACGACGGCCAGT-3') and M13R ( $5^{\prime}$-TCACACAGGAAACAGCTATGAC-3'). Positive products were purified and sequenced by Macrogen (Amsterdam, The Netherlands). Sequences were checked for possible chimeric origin using Pintail 1.1 software (Ashelford et al., 2005). For the 16S rRNA gene sequences, initial alignment of amplified sequences and close relatives identified with BLAST (Altschul et al., 1997) were performed using the SILVA alignment tool (Pruesse et al., 2007) and manually aligned with ARB (Ludwig et al., 2004). After alignment, the neighbor-joining algorithm of ARB package was used to generate the phylogenetic trees based on distance analysis for 16S rRNA genes. The robustness of inferred topologies 
was verified by bootstrap re-sampling analysis, using the same distance model (1000 replicates).

\section{ENUMERATION OF CELLS BY CARD-FISH}

The catalyzed reporter deposition fluorescence in situ hybridization (CARD-FISH) was performed using the protocol of Pernthaler et al. (2002) with some modifications. Briefly, $5 \mathrm{~g}$ of pooled sediments samples were fixed with formaldehyde $(2 \% \mathrm{v} / \mathrm{v}$ final concentrations) and left for $12 \mathrm{~h}$ at $4^{\circ} \mathrm{C}$. Fixed sediment samples were further incubated for at least $15 \mathrm{~min}$ with Tween 80 (final concentration, $1 \mathrm{mg} \mathrm{l}^{-1}$ ) and than sonicated during $20 \mathrm{~min}$ in an Ultrasonic cleaner (Branson 1200, Milan) for the bacterial dispersion (Kuwae and Hosokawa, 1999). Supernatant samples were then filtered onto polycarbonate membrane filters (type GTTP; pore size, $0.2 \mu \mathrm{m}$; diameter, $2.5 \mathrm{~cm}$; Sartorius, Göttingen, Germany). Filters for CARD-FISH counts were embedded in lowmelting point agarose $(0.1 \% \mathrm{wt} / \mathrm{vol}$, Sigma-Aldrich, Milan), dried at $37^{\circ} \mathrm{C}$ for $20 \mathrm{~min}$, and dehydrated with $95 \%$ ethanol. Embedded cells were permeabilized by $1 \mathrm{~h}$ of exposition with solution $\mathrm{A}$ (10 $\mathrm{mg} \mathrm{ml}^{-1}$ of lysozyme (Sigma-Aldrich, Milan); 0.5 M EDTA, $0.1 \mathrm{M}$ Tris- $\mathrm{HCl}$ [ $\mathrm{pH} 8.0]$ ) followed by the $30 \mathrm{~min}-$ long incubation with achromopeptidase $\left(60 \mathrm{U} \mathrm{ml}^{-1} ; 0.01 \mathrm{M} \mathrm{NaCl}, 0.01 \mathrm{M}\right.$ Tris$\mathrm{HCl}[\mathrm{pH} 8.0])$ at $37^{\circ} \mathrm{C}$. Filters were cut in sections and hybridized with $5^{\prime}$-horseradish peroxydase (HRP)-labeled oligonucleotide probes as described by Pernthaler et al. (2002). Probes used in this work are listed in Table 1. After the hybridization and amplification steps, slides were examined using a epifluorescence with Axioplan 2 Imaging (Zeiss; Carl Zeiss Inc., Thornwood, NY) microscope. All results were expressed as number of cells per gram of sediment.

\section{DETERMINATION OF CELL NUMBERS BY QUANTITATIVE PCR (qPCR)}

qPCR method was employed to determine the relative cell densities of Alcanivorax, Marinobacter, and Cycloclasticus in the sediment samples. Primers used through this study are listed in the Table 2. Primers were based on the sequences of Alcanivorax alkane hydroxylase gene (alkB2), Marinobacter alkane hydroxylase gene $(a l k B)$, and Cycloclasticus aromatic ring-hydroxylating dioxygenase ( $p h n A)$ gene. Primers for alKB2 and $p h n A$ genes were previously designed and validated for qPCR elsewhere (McKew et al., 2007; Gray et al., 2011). The primers specific for the alkB gene of Marinobacter were designed through this study using Primer Express software Primer Express software, version 2.0 (Applied Biosystems, Foster City, Calif.) with reference to the Marinobacter hydrocarbonoclasticus (FO203363).

Total DNA was extracted from $2.0 \mathrm{~g}$ of sediment samples collected at selected time scales from three different points inside the MSS by using a Bio101 FastDNA SPIN kit as described by the manufacturer (Bio101, Inc., Vista, Calif.). Extracted DNA was dissolved in $50 \mu \mathrm{l}$ of TE buffer ( $10 \mathrm{mM}$ Tris- $\mathrm{HCl}, 1 \mathrm{mM}$ EDTA $[\mathrm{pH} 7.5])$ and quantified using a NanoDrop ND-1000 spectrophotometer (Celbio). The quality of the extracted DNA was analyzed by electrophoresis on a $1.0 \%$ agarose gel. The qPCR was performed with absolute quantification method in an ABI Prism 7300 Real-time PCR System (Applied Biosystems) in a total volume of $25 \mu \mathrm{l}$, consisting $12.5 \mu \mathrm{l}$ of SYBR green master mix, $200 \mathrm{nM}$ of each primers, and $50 \mathrm{ng}$ of template DNA. The volume of each reaction was adjusted to $25 \mu \mathrm{l}$ by adding DNase-free water. The cycling parameters for the qPCR amplification were as follows: an initial denaturation step at $95^{\circ} \mathrm{C}$ for $10 \mathrm{~min}$, followed by 45 cycles of denaturation at $95^{\circ} \mathrm{C}$ for $15 \mathrm{~s}$ and annealing/elongation at $60^{\circ} \mathrm{C}$ for $60 \mathrm{~s}$. A dissociation step was added to check for primer-dimer formation. A tenfold serial dilution series of genomic DNA ranging from 10 to $10^{8}$ copies per reaction was used in triplicate to create the standard curve for quantification. Serial dilutions were prepared once for each target and used for real-time quantification. From the slope of each curve, PCR amplification efficiency was calculated as it described elsewhere (Rasmussen, 2001). Obtained slope values, (-3.17 for alkB2, -3.29 for alkB, and -3.37 for $p h n A$ ) fell within the optimal

Table 1 | CARD-FISH specific probes used in the present study.

\begin{tabular}{llcc}
\hline Probe & Sequence $\left(\mathbf{5}^{\prime}\right.$ to $\mathbf{3}^{\prime}$ ) of probe & FA (\%) & Source \\
\hline Eub338 & GCTGCCTCCCGTAGGAGT & 35 & Amann et al., 1990 \\
Marinobacter sp. & ATGCTTAGGATCTGCCCAGTAGTG & 20 & Karner and Fuhrman, 1997 \\
Cycloclasticus sp. & GGAAACCCGCCCAACAGT & 20 & Karner and Fuhrman, 1997 \\
Alcanivorax sp. & CGACGCGAGCTCATCCATCA & 20 & Karner and Fuhrman, 1997
\end{tabular}

FA: percentage of formamide in hybridization buffer.

Table 2 | qPCR primers used in the present study.

\begin{tabular}{|c|c|c|c|c|}
\hline Gene & Forward Reverse & Organism & $\begin{array}{l}\text { Amplification } \\
\text { efficiency (E) }\end{array}$ & Source \\
\hline alkB2 & $\begin{array}{l}\text { CGCCGTGTGAATGACAAGGG } \\
\text { CGACGCTTGGCGTAAGCATG }\end{array}$ & Alcanivorax & $99.6 \%$ & McKew et al., 2007 \\
\hline$a l k B$ & $\begin{array}{l}\text { TCCTTTGGTATGGCGCAGTT } \\
\text { ACGATCCTGTTCAAGCCGAG }\end{array}$ & Marinobacter & $97.3 \%$ & This study \\
\hline phnA & $\begin{array}{l}\text { CGTTGTGCGCATAAAGGTGCGG } \\
\text { СTTGCCCTTTCATACCCCGCC }\end{array}$ & Cycloclasticus & $96.2 \%$ & McKew et al., 2007 \\
\hline
\end{tabular}


range corresponding to an efficiency of 99.6, 97.3, and $96.2 \%$, respectively. Amplicon numbers were quantified against the standard curve using automatic analysis settings for the Ct values and baseline settings. Detected target genes were converted to cell density in sediments (cells gram ${ }^{-1}$ ) assuming that all three genes present as a single copy per genome.

\section{STATISTICAL ANALYSIS}

For statistical analyses, clones from each 16S crDNA library were separately considered to define phylotypes, or operational taxonomic units (OTUs) at cutoff of either 95 or $97 \%$ of sequence identity (Kemp and Aller, 2004). Clustering of sequences was performed using Dotur program (Schloss and Handelsman, 2005). Various parameters for each clone library, such as diversity index, rarefaction analysis, taxa, total clones, singletons, Shannon dominance, equitability, Simpson and chao 2 were calculated by PAST version 2.17c (http://folk.uio.no/ohammer/past; Hammer et al., 2001). Coverage values given as $C=1-\left(n_{1} / N\right)$, where $n_{1}$ is the number of clones which occurred only once in the library of $\mathrm{N}$ clones (Good, 1953), were calculated to determine how efficient clone libraries described the complexity of original bacterial community. The Primer 6 ecological software package developed by the Plymouth Marine Laboratory (Clarke and Gorley, 2006) was employed to perform the Hierarchical Cluster Analysis (HCA) (Clarke, 1993). We applied HCA on microbial biodiversity and Bray-Curtis similarity on relative abundance matrix of the OTUs detected at different sampling time. Significant difference of the microbial assemblages derived from both treated and control samples at the different sampling times was detected via the $P$-test significance and principal coordinates analysis (PCoA) using UniFrac program (http://bmf.colorado.edu/unifrac/index. psp, last access: 24 July 2008) (Lozupone et al., 2007). Differences in cell number per gram of sediment detected by DAPI, CARD, and qPCR between different samples was examined by analysis of variance (ANOVA) on ranks (Holm_Sindak method). Relative importance of each treatment group was investigated by Multiple Comparisons vs. Control Group comparison test. Calculations were carried out using SigmaStat software for Windows, ver.
3.1 (Copyright 1992-1995; Jandel Corporation). Differences were considered significant at $P<0.05$.

\section{NUCLEOTIDE SEQUENCE ACCESSION NUMBERS}

To avoid the submission of identical sequences obtained among 411 analyzed clones, only 98 distinguishing 16S rRNA gene sequences have been deposited in the DDBJ/EMBL/GenBank databases under accession numbers KF896304-KF896401.

\section{RESULTS}

\section{GEOCHEMICAL PROPERTIES OF THE SEDIMENTS}

Oxygen consumption in the external superficial sediments $(0-$ $5 \mathrm{~cm}$ ) was monitored during all 3 months of experimentation. These values were compared with BOD in the internal MSS sediments taken at the beginning $\left(\mathrm{T}_{0}\right)$, after 1 day $\left(\mathrm{T}_{1}\right), 1$ month $\left(\mathrm{T}_{29}\right)$, and after 3 months $\left(\mathrm{T}_{90}\right)$ of experimentation (Figure 2 ). Sediments outside of the MSS exhibited constant BOD rates of approximately $2.5 \mathrm{mg} \mathrm{O}_{2}$ day $^{-1} \mathrm{~kg}^{-1}$ during all period of experimentation, whereas the aerated sediments inside of the MSS demonstrated a progressive increment of oxygen consumption. Maximum of oxygen demand $\left(16.0 \mathrm{mg} \mathrm{O}_{2}\right.$ day $^{-1} \mathrm{~kg}^{-1}$ ) was obtained at $\mathrm{T}_{29}$ and afterwards the BOD values trended to diminish, reaching $10.0 \mathrm{mg} \mathrm{O}_{2} \mathrm{day}^{-1} \mathrm{~kg}^{-1}$ at the end of experiment. Outside the MSS, the amendment of the Bunker $\mathrm{C}$ furnace fuel oil turned initially oxygenated $\left(\mathrm{T}_{0}, \mathrm{E}_{\mathrm{h}}=77 \pm 4 \mathrm{mV}\right)$ sediments into highly reduced ones (Figure 3 ). The external sediments below $5 \mathrm{~cm}$ became oxygen-depleted already within 1 day after spiking, obviously due to the active respiration of aerobic heterotrophic microorganisms. The reduction potential of external sediments decreased continuously during the experiment and after 3 months reached the $E_{h}$ values of $-345 \mathrm{mV}$ in the deepest layers. In contrary, inside the MSS the sediments remained aerobic during all period of bioremediation effort.

\section{HYDROCARBON ANALYSIS}

Before the addition of $6500 \mathrm{ppm}$ of Bunker $\mathrm{C}$ fuel oil into the mesocosm, the total hydrocarbon concentration in the original Messina harbor sediments was estimated at the level of $120 \mathrm{ppm}$.

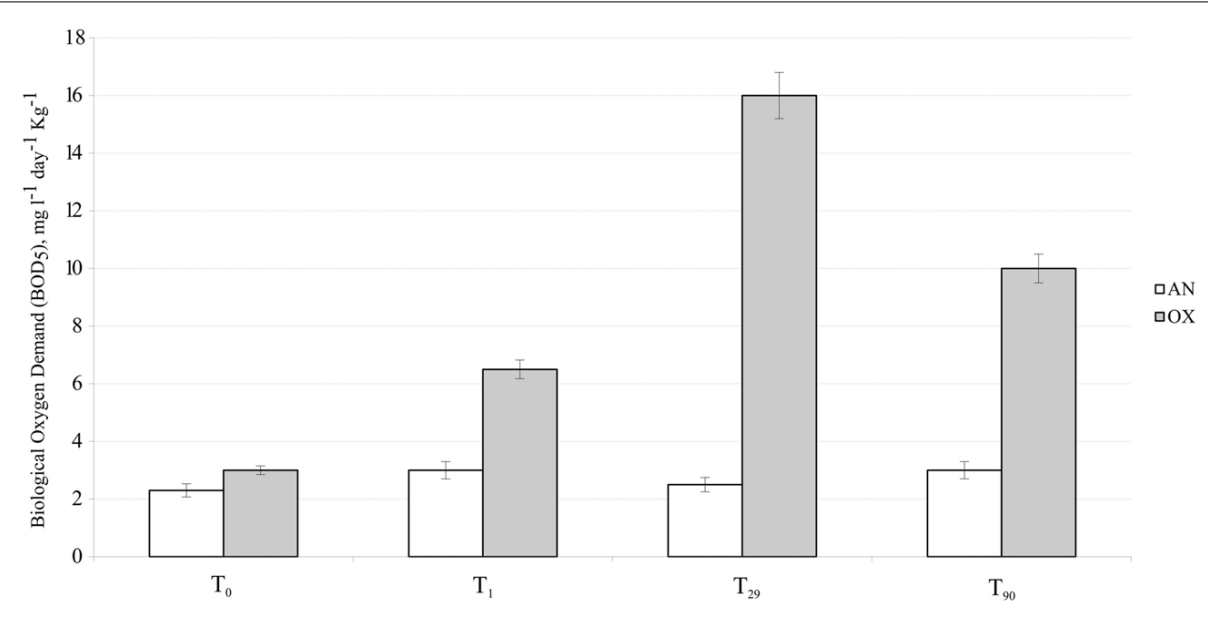

FIGURE 2 | Dynamic of oxygen consumption (BOD values) measured in MSS external (untreated) superficial sediments (white bars) and internal sediments (gray bars). Error bar indicates the standard deviation of triplicate measurements. 


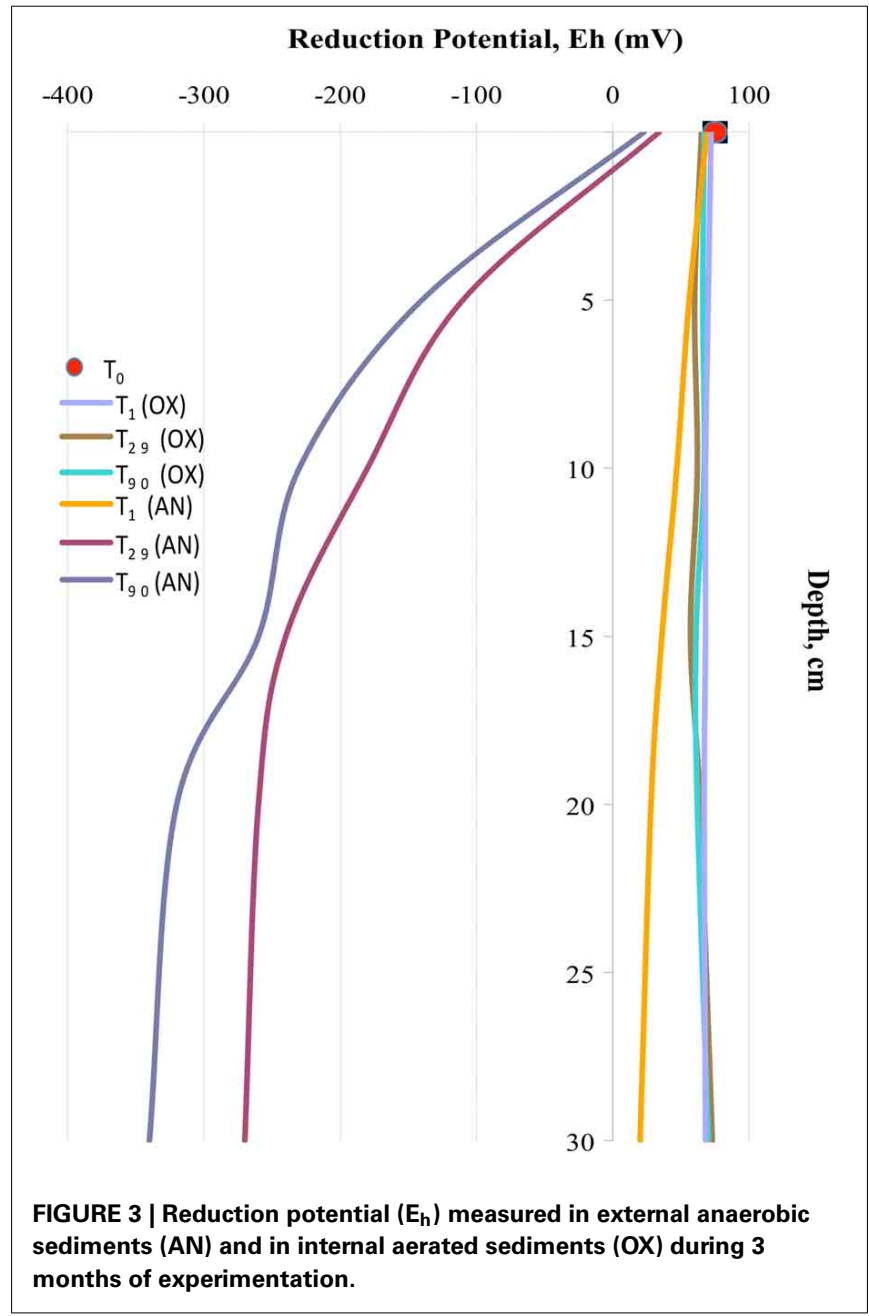

The PHs fingerprint analysis showed a clear dominance of alkylaromatic derivatives (97\%) over aliphatic hydrocarbons (3\%) (data not shown). Once Bunker $\mathrm{C}$ fuel oil was added to the sediments, the TERHC fraction mass balance was shifted toward the dominance of aliphatic and naphthenic hydrocarbons (70\%) over aromatics (30\%). The degree of the Bunker $\mathrm{C}$ fuel oil degradation in both, aerated MSS and in the untreated anoxic sediments was examined at the end of experiment $\left(\mathrm{T}_{90}\right)$. The concentration of PHs, especially aliphatic hydrocarbons was normalized using the pristane/phytane ratio, and the values obtained in triplicate subsamples were averaged. In the aerated internal MSS sediments, the total degradation of Bunker $\mathrm{C}$ fuel oil TERHC fraction was $97.7 \pm 0.9 \%$. In contrast, external anoxic sediments contained more than $81.8 \pm 1.2 \%$ of initially added Bunker $\mathrm{C}$ fuel oil. Additionally, we performed the gravimetrical analysis of total extracted hydrophobic fraction (TEHF) in the sediments. The TEHF values inside the MSS accounted for $780 \pm 80 \mathrm{mg} \mathrm{kg}^{-1}$ dry sediment weight, whereas in concordance with extremely slow biodegradation rates under anaerobic conditions, the external sediments contained more than $5400 \pm 120 \mathrm{mg} \mathrm{kg}^{-1}$ of hydrophobic material. As shown in subsequent section, TEH fraction seems be primarily responsible for the observed toxicity of Bunker C fuel oil.

\section{ECOTOXICOLOGICAL ANALYSIS}

According to standard guidelines of Italian Institute for Environmental Protection and Research (ISPRA, 2013), ecotoxicological analysis of hydrocarbon-contaminated sediments were carried out using the Microtox ${ }^{\circledR}$ luminescence and amphipod Corophium orientale bioassays. Eventual decrease in Microtox $^{\circledR}$ bioluminescence was measured on sediment pore water, whereas the rate of amphipods mortality was tested by direct exposition of $C$. orientale with the petroleum-contaminated sediments during 10 days. Following the EN12457 protocol, we combined the sediment pore water with sterile seawater in both $1: 2$ and 1:10 ratios (vol/vol) and no significant level of bioluminescence decay has been observed. As it reported in EN12457 protocol, Microtox ${ }^{\circledR}$ bioluminescent assay tested on sediment pore water typically exhibits an underestimated sensitivity against highly hydrophobic contaminants, such as PHs. This is mainly due to both extremely low solubility of these compounds in water and an almost irreversible adsorption to a sedimentary matrix. Corresponding to the standardized protocol described by Onorati et al. (1999), the toxicological analysis of the sediments was performed with amphipods $C$. orientale. Addition of Bunker $\mathrm{C}$ fuel oil to the sediments $\left(\mathrm{T}_{0}\right)$ caused the mortality in almost all organisms (98 $\pm 2 \%)$. The petroleum-contaminated external sediments remained highly toxic during all 3 months of experimentation with mortality indices exceeding 90\% (Figure 4). At the same time, the toxicity of polluted internal MSS sediments dropped almost twice after 1 month of aeration $\left(\mathrm{T}_{29}\right)$ and continued to decrease till the end of bioremediation treatment, approaching the vitality of $62 \%$ of amphipods exposed to $\mathrm{T}_{90}$ sediments. This indicated that the internal MSS sediment at $\mathrm{T}_{90}$ was significantly less toxic than their external counterpart.

\section{DIVERSITY AND SUCCESSION OF BACTERIAL COMMUNITIES DURING BIOREMEDIATION AND NATURAL SEDIMENT AGEING}

To monitor the succession of metabolically active microbial communities during the bioremediation treatment, five $16 \mathrm{~S}$ rRNA transcript libraries were established. 450 clones from these libraries were randomly selected and analyzed. Among those, 411 sequences were included into phygenetic analysis $\left(\mathrm{T}_{0}, 96\right.$ clones; $\mathrm{T}_{1}, 83$ clones; $\mathrm{T}_{29}, 80$ clones; $\mathrm{T}_{90}, 90$ clones and $\mathrm{T}_{900 \mathrm{O}}, 62$ clones). The majority of native $\mathrm{T}_{0}$ clones were affiliated with the Gammaproteobacteria (51\%), followed by the Alphaproteobacteria (22\%). Other proteobacteria, belonging to microaerophilic and anaerobic Epsilon- and Deltaproteobacteria were also present, although in significantly lower numbers (6 and $2 \%$ of all clones analyzed, respectively). Remaining fraction of $\mathrm{T}_{0}$ microbial community consisted of the members of Cyanobacteria (7\%), Chloroflexi (5\%), Verrucomicrobia (3\%), and Bacteroidetes (2\%) (Figure 5). At the level of the Class, the derived from members of Gammaproteobacteria were predominant in all analyzed MSS internal sediments, with percentage ranging from 73 to $88 \%$. There was a $50 \%$-reduction of Alphaproteobacteria observed during first month of sediment treatment (decrease from 22 to $11 \%$ ). Further on, their numbers returned to the initial $\left(\mathrm{T}_{0}\right)$ values by the end of experiment. No Deltaproteobacteriarelated organisms were detected in the internal MSS sediments throughout the experiment. A completely different scenario was 


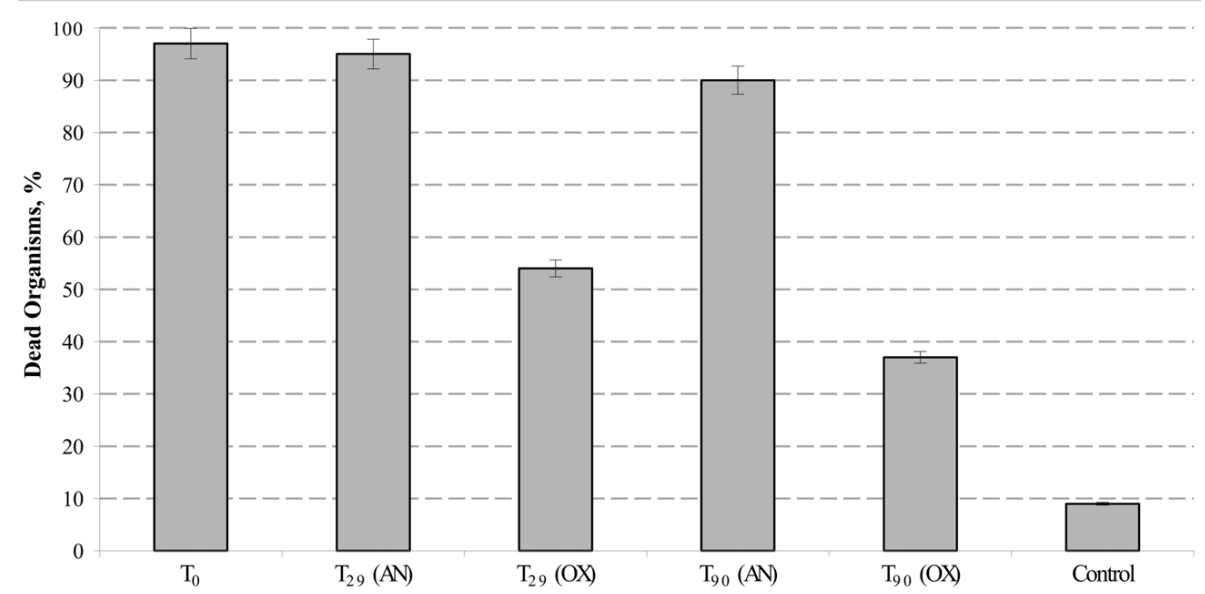

FIGURE 4 | Mortality of Corophium orientale organisms in polluted (AN), treated (OX), and control (native) sediments. Error bar indicates the standard deviation of duplicate measurements.

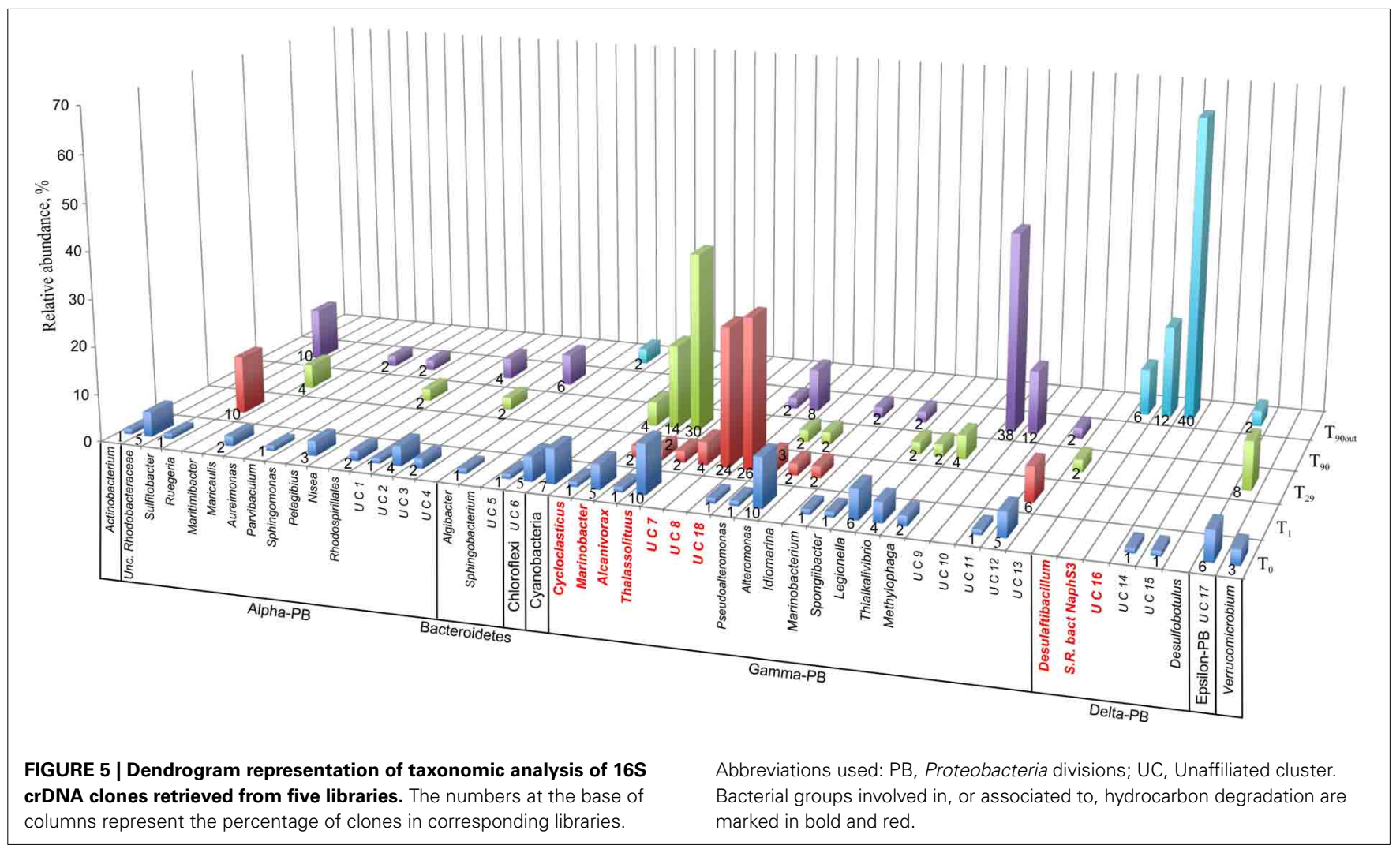

observed regarding the succession of microbial community thriving in the external anoxic sediments. As we mentioned above, after loading the Bunker $\mathrm{C}$ fuel oil, the sediments became highly reduced within a short period of time and were inhabited mainly by the members of Deltaproteobacteria (96.8\%). The analysis of $16 \mathrm{~S}$ rRNA transcripts from $\mathrm{T}_{900 \mathrm{~T}}$ clone library revealed a notable prevalence of hydrocarbon-degrading or hydrocarbon contamination-associated Deltaproteobacteria (90.3\%). In particular, almost two-thirds of all clones (40 out of 62 clones analyzed) were closely related to the uncultured bacterium RIIAN044 found in anoxic polluted sediments after the Prestige oil spill (Acosta González et al., 2013). More than 16\% of clones revealed $>98 \%$ of similarity to the deltaproteobacterium NaphS6, capable of naphthalene and 2-methylnaphthalene degradation (Wilkes et al., 2008). Almost $10 \%$ of $\mathrm{T}_{900 \mathrm{OUT}}$ clones were closely related to the $n$-alkanes- and $n$-alkenes-degrading strain Desulfatibacillum aliphaticivorans (Cravo-Laureau et al., 2004) (Figure 6). 


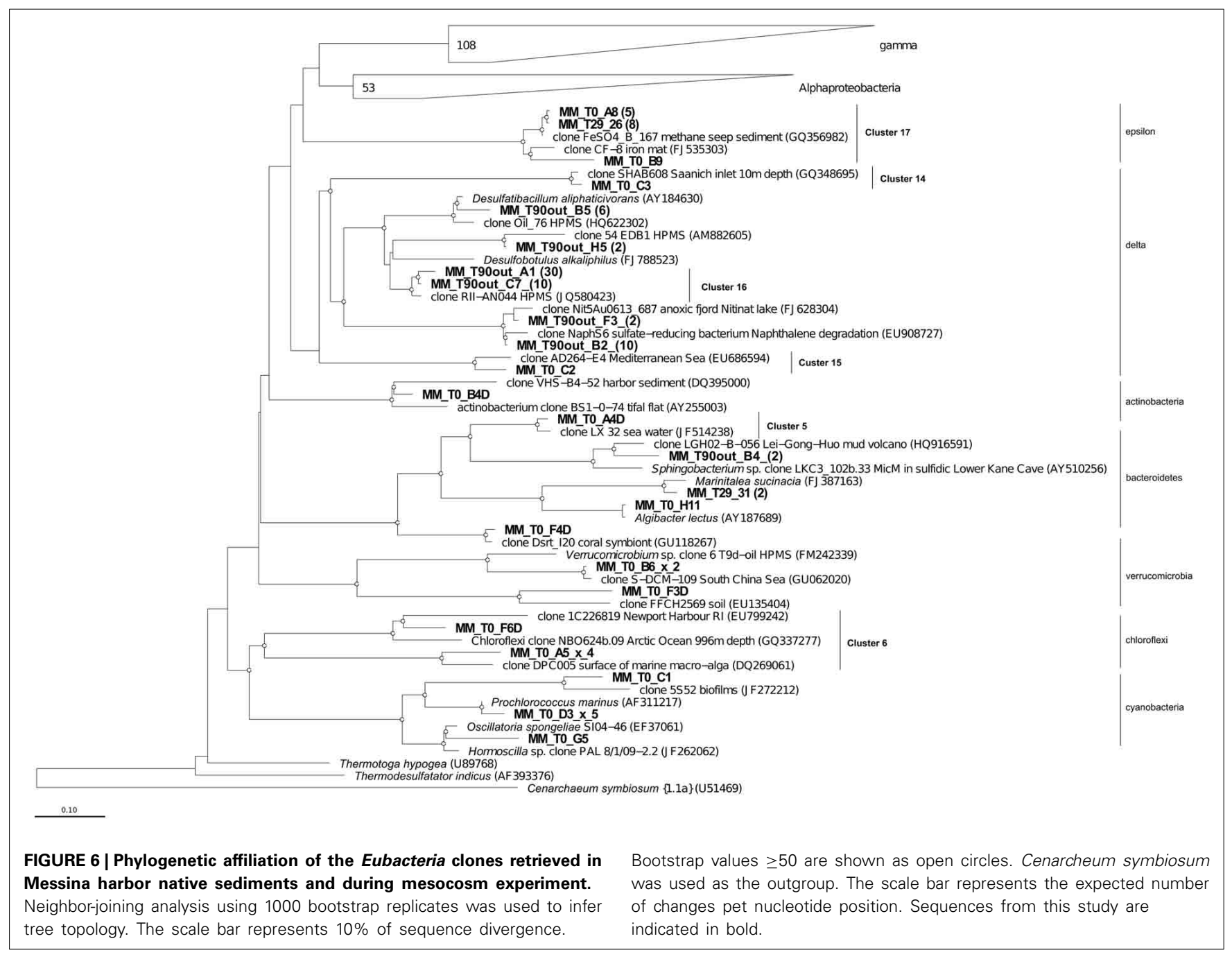

In accordance with the type of the contaminant load, the majority of analyzed clones had highest Blastn homologies with sequences related to $\mathrm{PH}$-degrading or petroleum contaminationassociated organisms belonging to the Gamma-, Alpha- and Deltaproteobacteria (Figures 6-8). At the genus and species level, more than $10 \%$ of initial microbial population was attributed to obligate marine hydrocarbonoclastic bacteria Thalassolituus oleivorans (Yakimov et al., 2004). This organism seemed to be sensitive to Bunker $\mathrm{C}$ fuel oil, since its abundance decreased to $2 \%$ after 1 day of oil exposition and disappeared afterwards. Three other OMHCB belonging to genera Alcanivorax, Cycloclasticus, and Marinobacter demonstrated similar dynamics, i.e., being in relative minority in the beginning of the experiment, they became predominant in $\mathrm{T}_{29}$ microbial community and disappeared in the $\mathrm{T}_{90}$ library (Figure 5). Noteworthy, the addition of Bunker $\mathrm{C}$ fuel oil to sediments drastically changed the structure of $\mathrm{T}_{1}$ microbial community and the proportion of aforementioned Gammaproteobacteria-related OMHCB decreased threefold compared with the initial population. In contrast, previously undetected organisms related to dinoflagellateassociated Rugeria sp. and to three deep-branching clusters of
Gammaproteobacteria accounted for $77 \%$ of all analyzed $\mathrm{T}_{1}$ clones. Having only $16 \mathrm{~S}$ rRNA gene sequences at our disposal, we cannot state that these uncultured organisms were involved in biodegradation activity, but they definitely possessed a remarkable resilience to the toxicity of Bunker $\mathrm{C}$ fuel oil (Païssé et al., 2008, 2010).

Additionally to $16 \mathrm{~S}$ rRNA-based analysis, the diversity and succession of both, total bacterial population and hydrocarbondegrading bacteria, was assessed through the combined application of CARD-FISH and qPCR. Using the Eubacteria-specific probe Eub338, the concentration of CARD-positive cells at the beginning of experiment was estimated at $2.98 \pm 0.17 \times 10^{6}$ cells gram ${ }^{-1}$ (Table 3 ). Their numbers decreased by $20 \%$ within 1 day after the oil spill simulation $(P<0.001, n=10)$ and reached initial values at the end of experiment $(2.79 \pm 0.12 \times$

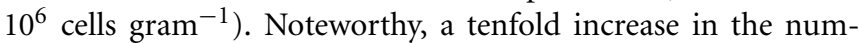
ber of CARD-positive cells $\left(2.95 \pm 0.11 \times 10^{7}\right.$ cells gram $\left.^{-1}\right)$ was detected after 29 days of oil spill, which fully corresponded to the observed dynamics of the BOD and clone libraries' values (Figure 2). Before the oil spill simulation $\left(\mathrm{T}_{0}\right)$, the fraction of Alcanivorax-related cells, detected with the CARD-FISH 


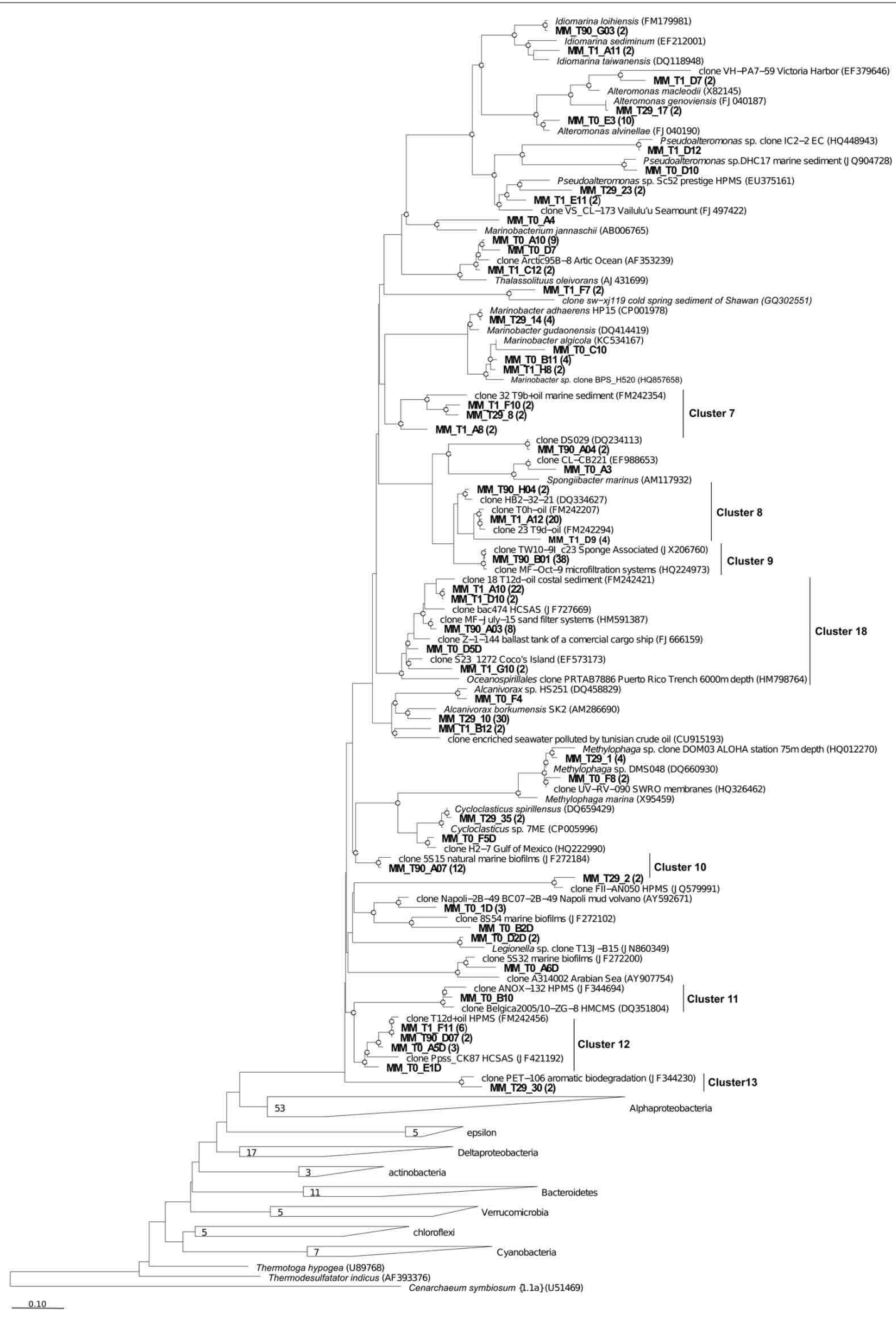

FIGURE 7 | Phylogenetic affiliation of the Gammaproteobacteria clones retrieved in Messina harbor sediments and in mesocosm experimen-

tation. Neighbor-joining analysis using 1000 bootstrap replicates was used to infer tree topology. The scale bar represents $10 \%$ of sequence divergence Bootstrap values $\geq 50$ are shown as open circles. Cenarcheum symbiosum was used as the out-group. Sequences obtained in this study are indicated in bold. 


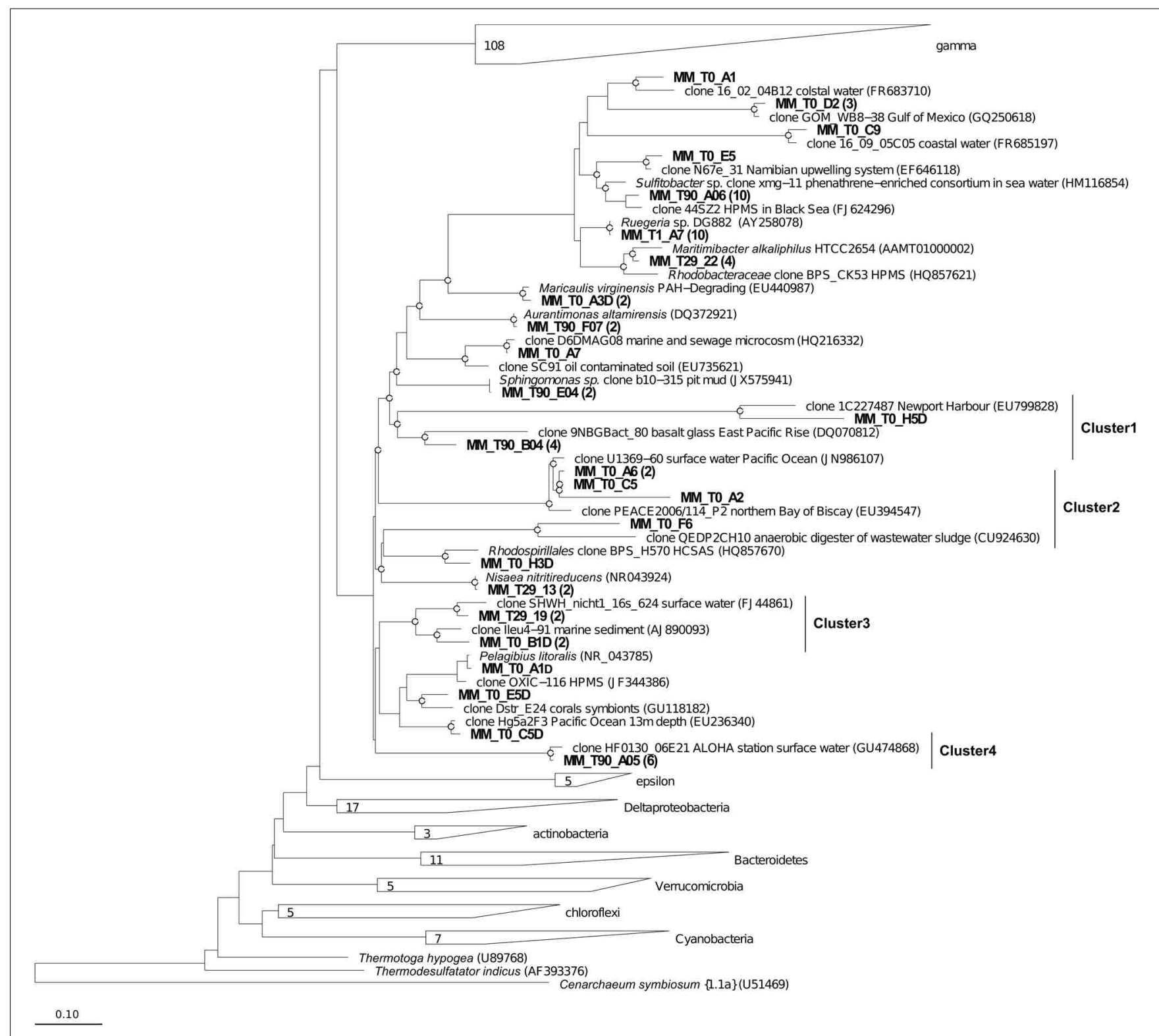

FIGURE 8 | Phylogenetic affiliation of the Alphaproteobacteria clones retrieved in Messina harbor sediments and in mesocosm experimentation. Neighbor-joining analysis using 1000 bootstrap replicates was used to infer tree topology. The scale bar represents $10 \%$ of sequence divergence. Bootstrap values $\geq 50$ are shown as open circles. Cenarcheum symbiosum was used as the outgroup. Sequences obtained in this study are indicated in bold. genus-specific probe, accounted for 7.7\% of all Eub338-positive cells. After the addition of Bunker $\mathrm{C}$ fuel oil, their abundance increased within 1 month up to $27.5 \%$. According to the analysis of $16 \mathrm{~S}$ crDNA clone libraries, Alcanivorax became extinct in microbial community thriving in the MSS internal sediments at the end of experiment. Dynamics of the Marinobacter-related bacteria was comparable with that of Alcanivorax population, with the only exception that the Marinobacter cells decreased their abundance by $44 \%$ at $\mathrm{T}_{1}$, likely due to the higher sensitivity to the load of fuel oil. Compared to an initial density, their population increased twofold at $\mathrm{T}_{29}$, from $4.5 \pm 0.2$ to $9.0 \pm 0.1 \times 10^{5}$ cells $\mathrm{g}^{-1}$. Although due to the overwhelming growth of Alcanivorax, the relative abundance of Marinobacter during bioremediation experiment has never exceeded its initial values $(15.2 \%$ of all Eub338-stained cells at $\mathrm{T}_{0}$ ) and at $\mathrm{T}_{29}$ (corresponding to the maximum of cell density in MSS) accounted for only 3\% of total microbial community. Bacteria stained with Cycloclasticusspecific CARD-FISH probe, initially present in mesocosm sedi-

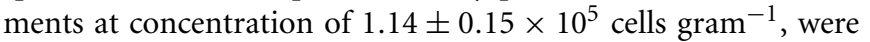
not detected at $T_{1}$, whereas their concentration increased four times after 1 month of the oil spill simulation. Similarly to the dynamics of Alcanivorax, neither Marinobacter, nor Cycloclasticus were present in the MSS microbial community at the end of experiment. 
Succession of hydrocarbon-degrading bacteria during the sediment bioremediation was additionally quantified by qPCR. Based on the a priori higher sensitivity of qPCR approach, obtained numbers were slightly higher than those from taxonspecific CARD-FISH data. Nevertheless, obtained results remarkably corroborated with CARD-FISH counts and the general trend in Alcanivorax, Marinobacter, and Cycloclasticus dynamics was identical (Table 3). None of these hydrocarbon-degrading bacteria were detected by qPCR at the end of experiment.

\section{STATISTICAL ANALYSIS OF BACTERIAL DIVERSITY}

As it shown in Table 4, the diversity index and coverage values have been calculated for each 16S rRNA transcript library. Based on sequence similarity threshold for OTU definition $\geq 97 \%$ (Rosselló-Mora and Amann, 2001), a total of 93 different OTUs were discerned. The rarefaction analysis did not demonstrate the saturation in any library (data not shown), however, the coverage values varying between 0.64 ( $\mathrm{T}_{0}$ library) and 0.92

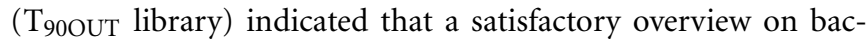
terial community was obtained. As reflected by the high values of Simpson, Shannon and the number of missing species provided by Chao-2, the highest bacterial diversity was observed in original sediments $\left(\mathrm{T}_{0}\right)$. Bacterial biodiversity was drastically affected by Bunker $\mathrm{C}$ fuel oil addition, decreasing the Simpson, Shannon and Equitability values, due to strong selection for both petroleum contamination-resilient and hydrocarbon-degrading bacteria (Harayama et al., 1999; Kasai et al., 2001, 2002; Syutsubo et al., 2001). Dominance index reached the highest value at $\mathrm{T}_{29}$ and $\mathrm{T}_{90}$. After 1 month of aeration, the microbial population of the internal MSS sediments was dominated by OMHCBs, whereas at the end of experiment, the dominant Cluster 9 of the Gammaproteobacteria accounted for $42 \%$ of all $\mathrm{T}_{90}$ clones. This cluster consists of organisms recovered from pristine seawater and marine sediments. As mentioned above, the microbial community of anaerobic external sediments T900UT $_{90}$ was totally different compared with aerated internal sediments. Both fuel oil contamination and rapid development of anaerobiosis have selected a very specialized and poorly diverse microbial population (5 OTUs; Dominance 0.44; Coverage 91\%). These data were confirmed by the HCA and UniFrac PCoA analyses. At the end of the experiment, the microbial communities thriving in the
MSS external ( $\left.\mathrm{T}_{90 \mathrm{OUT}}\right)$ and the internal $\left(\mathrm{T}_{90}\right)$ sediments were significantly different from each other $(\mathrm{P} 1=50.85 \%$ and $\mathrm{P} 2=$ $31.39 \%)$. Noteworthy, both applied statistical analyses confirmed that comparing with $\mathrm{OMHCB}$-enriched $\mathrm{T}_{29}$ population, the $\mathrm{T}_{90}$ microbial community was more similar to those recovered from early stages of the experiment ( $\mathrm{T}_{0}$ and $\mathrm{T}_{1}$ libraries) (Figure 9). This finding indirectly hints at the process of self-recovery of petroleum-contaminated sediments, which was confirmed by GC analysis of the contaminated sediments in and outside the MSS.

\section{DISCUSSION}

The influence of the massive Bunker $\mathrm{C}$ fuel oil load upon the microbial population of coastal sediments collected in Messina harbor and their recovery was investigated during 3 months in the mesocosms experiment. These sediments chronically polluted with alkylnaphthalenes were chosen since the autochthonous microbial community is likely adapted to the steady presence of PHs and consequently may exhibit a higher biodegradation ability than those from pristine environments (Païssé et al., 2008, 2010). Accordingly, the fraction of the OMHCB genera Alcanivorax Cycloclasticus Marinobacter and Thalassolituus, usually imperceptible in pristine marine environments (Yakimov et al., 2007), accounted for a fifth part of the native microbial community of Messina harbor sediments. To simulate accidental oil spill we spiked $1000 \mathrm{~kg}$ sandy sediments with Bunker C fuel oil (6500 mg

\section{Table 4 | Diversity indices calculated for the five clone libraries created at different time of aeration and sediment ageing.}

\begin{tabular}{lccccc}
\hline Diversity index & $\mathbf{T}_{\mathbf{0}}$ & $\mathbf{T}_{\mathbf{1}}$ & $\mathbf{T}_{\mathbf{2 9}}$ & $\mathbf{T}_{\mathbf{9 0}}$ & $\mathbf{T}_{\mathbf{9 0 0}} \mathbf{T}$ \\
\hline Taxa/(OTUs)_S & 46 & 16 & 14 & 12 & 5 \\
Number of clones & 96 & 83 & 80 & 90 & 62 \\
Dominance_D & 0.04 & 0.15 & 0.22 & 0.24 & 0.44 \\
Simpson_1-D & 0.96 & 0.85 & 0.78 & 0.76 & 0.55 \\
Shannon_H & 3.5 & 2.31 & 2.08 & 1.89 & 1.09 \\
Equitability_J & 0.91 & 0.84 & 0.78 & 0.76 & 0.68 \\
Chao-2 & 104.1 & 16 & 14 & 12 & 5 \\
Singletons & 31 & 1 & 0 & 0 & 0 \\
Doubletones & 7 & 10 & 8 & 6 & 2 \\
Coverage & 0.64 & 0.74 & 0.77 & 0.87 & 0.92 \\
\hline
\end{tabular}

Table 3 | CARD-FISH and qPCR cell number quantification in the MSS internal sediment during the bioremediation treatment.

\begin{tabular}{|c|c|c|c|c|c|}
\hline \multirow[t]{2}{*}{ Method } & \multicolumn{5}{|c|}{ Cell numbers, $10^{5} \times$ g sediments ${ }^{-1} \pm S D$} \\
\hline & Probe/primers & $\mathbf{T}_{0}$ & $\mathbf{T}_{1}$ & $\mathbf{T}_{29}$ & $T_{90}$ \\
\hline \multirow[t]{4}{*}{ CARD-FISH } & Eubacteria & $29.8 \pm 1.7$ & $23.6 \pm 1.5$ & $295.0 \pm 11.0$ & $27.9,1.2$ \\
\hline & Alcanivorax sp. & $2.3 \pm 0.1$ & $3.1 \pm 0.2$ & $81.0 \pm 1.3$ & ND \\
\hline & Marinobacter sp. & $4.5 \pm 0.2$ & $2.6 \pm 0.1$ & $9.0 \pm 0.1$ & ND \\
\hline & Cycloclasticus sp. & $1.2 \pm 0.2$ & ND & $4.9 \pm 0.1$ & ND \\
\hline \multirow[t]{3}{*}{ qPCR* } & alkB2 & $5.17 \pm 0.17$ & $4.73 \pm 0.18$ & $94.60 \pm 3.80$ & ND \\
\hline & $a l k B$ & $7.90 \pm 0.23$ & $3.50 \pm 0.20$ & $15.30 \pm 2.00$ & ND \\
\hline & phnA & $2.10 \pm 0.16$ & $3.78 \pm 0.12 \times 10^{-3}$ & $7.13 \pm 0.28$ & ND \\
\hline
\end{tabular}

*These values mean the average number of cells detected in triplicate from three individual subsamples of sediments collected in different parts of MSS. 


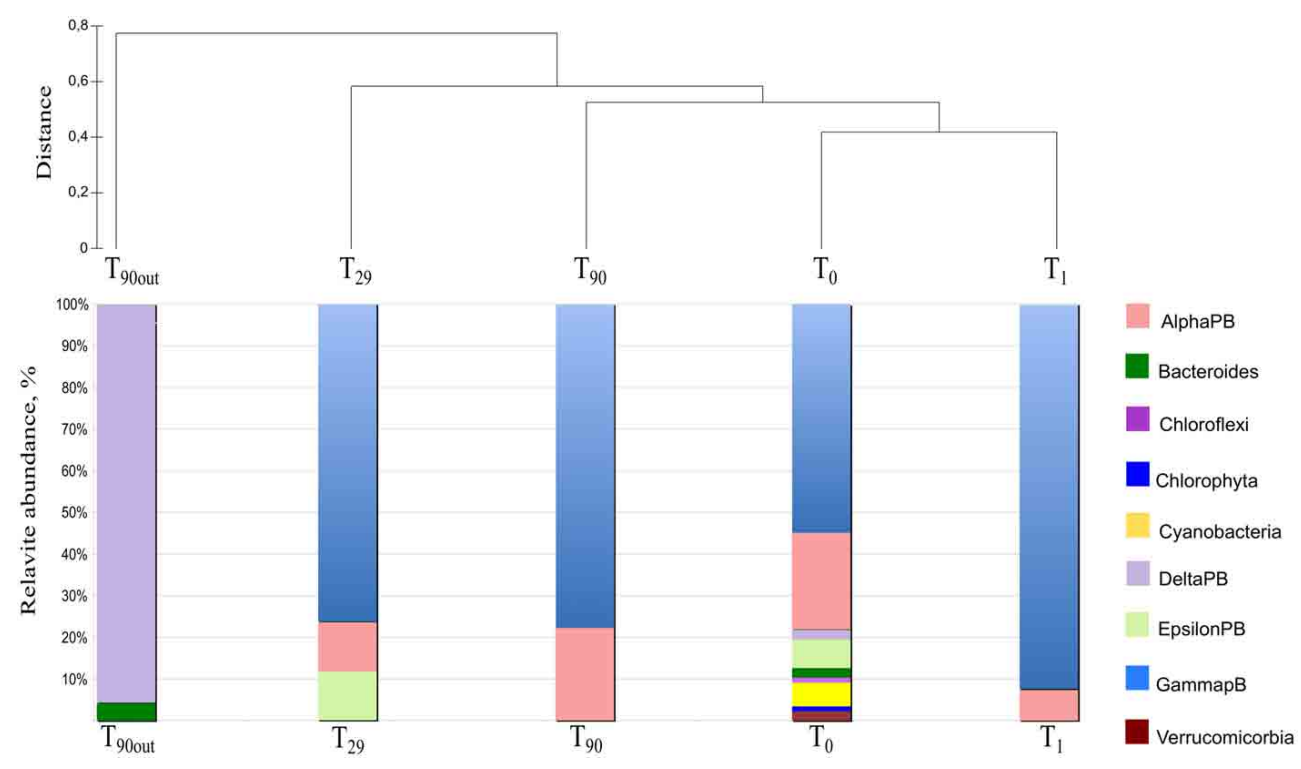

FIGURE 9 |Dendrogram of microbial biodiveristy and similarity analysis of the 16S rRNA transcripts detected at different sampling time and treatment. The UPGMA cluster analysis was obtained by using group average clustering from Euclidean distance on relative abundance matrix of OTUs detected in the analyzed libraries. $\mathrm{kg}^{-1}$ ). This type of heavy fuel oil is frequently used by the cargo and tanker ships and is generally more complex in composition and impurities than distilled fuels. Bunker $\mathrm{C}$ fuel oil includes about $25 \%$ polyaromatic, $15 \%$ aliphatic, $45 \%$ naphthenic and $15 \%$ non-hydrocarbon compounds (Clark et al., 1990) As it generally observed, after the oil spill reaches a shoreline, the oil burial is the main mechanism of the pollution dispersal. This results in intense oiling of subsurface sediments and consequent reduction in oxygen concentration due to initial activation of aerobic hydrocarbon-degrading microorganisms (Albaigés et al., 2006; Acosta González et al., 2013). Once $\mathrm{O}_{2}$ concentration drops to zero, the degradation rates of both aliphatic and aromatic $\mathrm{PHs}$ decrease significantly. According with this observation, the oil cleanup was very marginal, and $>80 \%$ of initially added Bunker $C$ fuel oil was extracted from the anaerobic external sediments after 3 months of oil spill simulation. At the end of experiment, analysis of microbial community of the MSS external sediments revealed the overwhelming dominance of the Deltaproteobacteria.

The stimulation of autochthonous bacteria to tackle the pollution in contaminated environment is widely used in the remediation of aerobic sites (Harayama et al., 2004). However, this technology is hardly applicable to oxygen-depleted marine sediments. Additionally, due to high probability of contaminant spreading while removing, the application of ex-situ remediation technologies is severely limited. To initiate the self-cleaning process in sediments driven by indigenous aerobic OMHCB, we used in situ aeration of polluted anoxic sediments in specially designed MSS. It is generally assumed, that petroleum contamination induced drastic changes in the bacterial community structure associated with a decrease of diversity (Grötzschel et al., 2002; Röling et al., 2002; Yakimov et al., 2005, 2007; Head et al., 2006; Bordenave et al., 2007). These changes were referred to both toxic effect of PHs and a strong selection toward highly specialized hydrocarbon-degrading microorganisms (Harayama et al., 1999; Kasai et al., 2001; Grötzschel et al., 2002; Yakimov et al., 2005, 2007). Accordingly, the most drastic shifts in the MSS bacterial community dynamic was observed at the beginning and after 1 month of the oil spill. As revealed by 16S crDNA clone library analysis, more than a half of MSS microbial population at $\mathrm{T}_{29}$, belonged to Alcanivorax (43\%), Cycloclasticus (7\%) and Marinobacter (5\%), the genera of OMHCB, known to play a pivotal role in petroleum degradation in marine environments (Harayama et al., 1999; Röling et al., 2002, 2004; Yakimov et al., 2007). Noteworthy, the dominance of these OMHCB genera was confirmed by both CARD-FISH and qPCR analyses. At the end of the treatment, the level of TERHC degradation in the MSS internal sediments was almost $98 \%$, and the resulting microbial community was characterized by an almost complete extinction of OMHCBs. Both HCA and UniFrac PCoA statistic analyses of the OTUs abundance matrix indicated that the structure of $\mathrm{T}_{90}$ microbial community was more similar to initial microbial community structures. As a consequence of successful bioremediation, the Corophium orientale eco-toxicological bioassay revealed that toxicity of the MSS internal sediments was substantially lower compared with the untreated external sediments. Thus, to the best of our knowledge, our studies for the first time demonstrated that petroleum-contaminated anaerobic marine sediments could be efficiently recovered by their capping and in situ aeration, thus stimulating the self-cleaning potential due to reawakening of residing aerobic OMHCBs.

\section{ACKNOWLEDGMENTS}

This work was funded by the European Community Projects ULIXES (FP7-KBBE-2010-4 Project 266473 “Unravelling and 
exploiting Mediterranean Sea microbial diversity and ecology for xenobiotics' and pollutants' clean-up") and KILL-SPILL (FP7KBBE-2012.3.5-01-4 Project 312139 "Integrated Biotechnological Solutions for Combating Marine Oil Spills"). We would like to thank all partners of these projects for their useful discussions.

\section{REFERENCES}

Acosta González, A., Rosselló Móra, R., and Marqués, S. (2013). Characterization of the anaerobic microbial community in oil polluted subtidal sediments: aromatic biodegradation potential after the Prestige oil spill. Environ. Microbiol. 15, 77-92. doi: 10.1111/j.1462-2920.2012.02782.x

Albaigés, J., Morales-nin, B., and Villas, F. (2006). The Prestige oil spill: a scientific response. Mar. Pollut. Bull. 53, 205-207. doi: 10.1016/j.marpolbul.2006.03.012

Altschul, S. F., Madden, T. L., Schaffer, A. A., Zhang, J., Zhang, Z., Miller, W., et al. (1997). Gapped BLAST and PSI-BLAST: a new generation of protein database search programs. Nucleic Acids Res. 25, 3389-3402. doi: 10.1093/nar/25.17.3389

Amann, R. I., Krumholz, L., and Stahl, D. A. (1990). Fluorescent-oligonucleotide probing of whole cells for determinative, phylogenetic, and environmental studies in microbiology. J. Bacteriol. 172, 762-770.

Ashelford, K. E., Chuzhanova, N. A., Fry, J. C., Jones, A.J., and Weightman, A. J. (2005). At least 1 in 20 16S rRNA sequence records cur- rently held in public repositories is estimated to contain substantial anomalies. Appl. Environ. Microbiol. 71, 7724-773. doi: 10.1128/AEM.71.12.7724-7736.2005

Benton, M. J., Malott, M. L., Knight, S. S., Cooper, C. M., and Benson, W. H. (1995). Influence of sediment composition on apparent toxicity in a solid phase test using bioluminescent bacteria. Environ. Toxicol. Chem. 14, 411-414. doi: 10.1002/etc.5620140309

Bordenave. S., Goñi-Urriza, M. S., Caumette, P., and Duran, R. (2007). Effects of heavy fuel oil on the bacterial community structure of a pristine microbial mat. Appl. Environ. Microbiol. 73, 6089-6097. doi: 10.1128/AEM.01352-07

Bulich, A. A., Greene, M. W., and Underwood, S. R. (1992). "Measurement of soil and sediment toxicity to bioluminescent bacteria when in direct contact for a fixed time period," in Memorias de Water Environment Federation, 65th Annual Conference and Exposition (Nueva Orleans, Louisiana), 53-64.

Clark, R. N., King, T. V. V., Klejwa, M., Swayze, G., and Vergo, N. (1990). High spectral resolution reflectance spectroscopy of minerals. J. Geophys. Res. 95, 12653-12680. doi: 10.1029/JB095iB08p12653

Clarke, K. R. (1993). Non parametric multivariate analyses of changes in community structure. Aust. J. Ecol. 18, 117-143. doi: 10.1111/j.1442-9993.1993. tb00438.x

Clarke, K. R., and Gorley, R. N. (2006). PRIMER v6. User Manual and Tutorial. Plymouth: PRIMER-E.

Cravo-Laureau, C., Matheron, R., Cayol, J. L., Joulian, C., and Hirschler-Réa, A. (2004). Desulfatibacillum aliphaticivorans gen. nov., sp. nov., an n-alkane-and n-alkene-degrading, sulfate-reducing bacterium. Int. J. Syst. Evol. Microbiol. 54, 77-83. doi: 10.1099/ijs.0.027170-0

Dyksterhouse, S. E., Gray, J. P., Herwig, R. P., Lara, J. C., and Staley, J. T. (1995). Cycloclasticus pugetii gen. nov., sp. nov., an aromatic hydrocarbon-degrading bacterium from marine sediments. Int. J. Syst. Bacteriol. 45, 116-123. doi: 10.1099/00207713-45-1-116

Engelen, B., and Cypionka, H. (2009). The subsurface of tidal-flat sediments as a model for the deep biosphere. Ocean Dynam. 59, 385-391. doi:10.1007/s10236008-0166

Ferraro, G., Bernardini, A., David, M., Meyer-Roux, S., Muellenhoff, O., Perkovic, M., et al. (2007). Towards an operational use of space imagery for oil pollution monitoring in the Mediterranean basin: a demonstration in the Adriatic Sea. Mar. Pollut. Bull. 54, 403-422. doi: 10.1016/j.marpolbul.2006.11.022

Gertler, C., Yakimov, M. M., Malpass, M. C., and Golyshin, P. N. (2010). "Shippingrelated accidental and deliberate release into the environment," in Handbook of Hydrocarbon and Lipid Microbiology, ed K. N. Timmis (Berlin, Heidelberg: Springer), 243-256. doi: 10.1007/978-3-540-77587-4_16

Golyshin, P. N., Chernikova, T. N., Abraham, W. R., Lünsdorf, H., Timmis, K. N., and Yakimov, M. M. (2002). Oleiphilaceae fam. nov., to include Oleiphilus messinensis gen. nov., sp nov., a novel marine bacterium that obligately utilizes hydrocarbons. Int. J. Syst. Evol. Microbiol. 52, 901-911. doi: 10.1099/ijs.0. 01890-0

Good, I. J. (1953). The population frequencies of species and the estimation of population parameters. Biometrika. 40, 237-264. doi: 10.2307/2333344
Gray, S. B., Classen, A. T., Kardol, P., Yermakov, Z., and Miller, R. M. (2011). Multiple climate change factors interact to alter soil microbial community structure in an old-field ecosystem. Soil Sci. Soc. Am. J. 75, 2217-2226. doi: 10.2136/ sssaj2011.0135

Grötzschel, S., Köster, J., Abed, R. M. M., and De Beer, D. (2002). Degradation of petroleum model compounds immobilized on clay by a hypersaline microbial mat. Biodegradation 13, 273-283. doi: 10.1023/A:1021263009377

Hammer, Ø., Harper, D. A. T., and Ryan, P. D. (2001). PAST: palaeontological statistics software package for education and data analysis. Palaeontol. Electron. 4, 9.

Hara, A., Syutsubo, K., and Harayama, S. (2003). Alcanivorax which prevails in oil-contaminated seawater exhibits broad substrate specificity for alkane degradation. Environ. Microbiol. 5, 746-753. doi: 10.1046/j.1468-2920.2003.00468.x

Harayama, S., Kasai, Y., and Hara, A. (2004). Microbial communities in oilcontaminated seawater. Curr. Opin. Biotechnol. 15, 205-214. doi: 10.1016/jcopbio.2004.04.002

Harayama, S., Kishira, H., Kasai, Y., and Shutsubo, K. (1999). Petroleum biodegradation in marine environments. J. Mol. Microbiol. Biotechnol. 1, 63-70.

Head, I. M, Jones, D. M, and Röling, W. F. (2006). Marine microorganisms make a meal of oil. Nat. Rev. Microbiol. 4, 173-182. doi:10.1038/nrmicro1348

ISPRA. (2013). "Batterie di saggi ecotossicologici per sedimenti e acque interne," in Manuali di Ecotossicologia, eds ISPRA-settore editoria. ISBN: 978-88-4480607-1.

Karner, M. B., and Fuhrman, J. (1997). Determination of active marine bacterioplankton: a comparison of universal 16S rRNA probes, autoradiography, and nucleoid staining. Appl. Environ. Microbiol. 63, 1208-1213.

Kasai, Y., Kishira, H., Sasaki, T., Syutsubo, K., Watanabe, K., and Harayama, S. (2002). Predominant growth of Alcanivorax strains in oil contaminated and nutrient supplemented seawater. Environ. Microbiol. 4, 141-147. doi: 10.1046/j.1462-2920.2002.00275.x

Kasai, Y., Kishira, H., Syutsubo, K., and Harayama, S. (2001). Molecular detection of marine bacterial populations on beaches contaminated by the Nakhodka tanker oil spill accident. Environ. Microbiol. 3, 246-255. doi: 10.1046/j.14622920.2001.00185. $\mathrm{x}$

Kemp, P. F., and Aller, J. Y. (2004). Bacterial diversity in aquatic and other environments: what $16 \mathrm{~S}$ rDNA libraries can tell us. FEMS Microbiol. Ecol. 47, 161-177. doi: 10.1016/S0168-6496(03)00257-5

Kuwae, T., and Hosokawa, Y. (1999). Determination of the abundance and biovolume of bacteria in sediments by dual staining with $4^{\prime}, 6$-diamidino-2phenylindole and acridine orange: relationship to dispersion treatment and sediment characteristics. Appl. Environ. Microbiol. 65, 3407-3412.

Lane, D. J. (1991). “16/23S rRNA sequencing," in Nucleic Acid Techniques in Bacterial Systematics, eds E. Stackerbrandt and M. Goodfellow (New York, NY: Wiley), 115-175.

Lozupone, C. A., Hamady, M., Kelley, S. T., and Knight, R. (2007). Quantitative and qualitative $\beta$ diversity measures lead to different insights into factors that structure microbial communities. Appl. Environ. Microbiol. 73, 1576-1585. doi: 10.1128/AEM.01996-06

Ludwig, W., Strunk, O., Westram, R., Richter, L., Meier, H., Yadhukumar, et al. (2004). ARB: a software environment for sequence data. Nucleic Acids Res. 32, 1363-1371. doi: 10.1093/nar/gkh293

McKew, B.A., Coulon, F., Yakimov, M. M., Denaro, R., Genovese, M., Smith, C. J., et al. (2007). Efficacy of intervention strategies for bioremediation of crude oil in marine systems and effects on indigenous hydrocarbonoclastic bacteria. Environ. Microbiol. 9, 1562-1571. doi: 10.1111/j.1462-2920.2007.01277.x

Microtox System Operating Manual. (1982). Microbics Operations. Carlsbad, CA: Beckman Instruments, Inc.

Onorati, F., Bigongiari, N., Pellegrini, D., and Giuliani, S. (1999). The suitability of Corophium orientale (Crustacea, Amphipoda) in harbour sediment toxicity bioassessment. Aquat. Ecosys. Health Manage. 2, 465-473. doi: 10.1016/S14634988(99)00030-5

Païssé, S., Coulon, F., Goñi-Urriza, M., Peperzak, L., McGenity, T. J., and Duran, R. (2008). Structure of bacterial communities along a hydrocarbon contamination gradient in a coastal sediment. FEMS Microbiol. Ecol. 66, 295-305. doi: 10.1111/j.1574-6941.2008.00589

Païssé, S., Goñi-Urriza, M., Coulon, F., and Duran, R. (2010). How a bacterial community originating from a contaminated coastal sediment responds to an oil input. Microb. Ecol. 60, 394-405. doi: 10.1007/s00248-010-9721-7

Pernthaler, A., Pernthaler, J., and Amann, R. (2002). Fluorescence in situ hybridization and catalyzed reporter deposition for the identification of marine 
bacteria. Appl. Environ. Microbiol. 68, 3094-3101. doi: 10.1128/AEM.68.6.30943101.2002

Pruesse, E., Quast, C., Knittel, K., Fuchs, B. M., Ludwig, W. G., Peplies, J., et al. (2007). SILVA: a comprehensive online resource for quality checked and aligned ribosomal RNA sequence data compatible with ARB. Nucleic Acids Res. 35, 7188-7196. doi: 10.1093/nar/gkm864

Psarros, G., Skjong, R., and Eide, M. S. (2010). Under-reporting of maritime accidents. Accid. Anal. Prev. 42, 619-625. doi: 10.1016/j.aap.2009.10.008

Rasmussen, R. (2001). "Quantification on the LightCycler," in Rapid Cycle RealTime PCR, Methods and Applications, eds S. Meuer, C. Wittwer, and K. Nakagawara (Heidelberg: Springer Press), 21-34. doi: 10.1007/978-3-64259524-0_3

Ringwood, A. H., DeLorenzo, M. E., Ross, P. E., and Holland, A. F. (1997). Interpretation of Microtox ${ }^{\circledR}$ solid phase toxicity tests: the effects of sediment composition. Environ. Toxicol. Chem. 16, 1135-1140. doi: $10.1002 /$ etc. 5620160607

Rocchetti, L., Beolchini, F., Ciani, M., and Dell'Anno, A. (2011). Improvement of bioremediation performance for the degradation of petroleum hydrocarbons in contaminated sediments. Appl. Environ. Soil Sci. 2011:319657. doi: $10.1155 / 2011 / 319657$

Röling, W. F., Milner, M. G., Jones, D. M., Fratepietro, F., Swannell, R. P., Daniel, F., et al. (2004). Bacterial community dynamics and hydrocarbon degradation during a field-scale evaluation of bioremediation on a mudflat beach contaminated with buried oil. Appl. Environ. Microbiol. 70, 2603-2613. doi: 10.1128/AEM.70.5.2603-2613.2004

Röling, W. F., Milner, M. G., Jones, D. M., Lee, K., Daniel, F., Swannell, R. P., et al. (2002). Robust hydrocarbon degradation and dynamics of bacterial communities during nutrient-enhanced oil spill bioremediation. Appl. Environ. Microbiol. 68, 5537-5548. doi: 10.1128/AEM.68.11.5537-5548.2002

Rosselló-Mora, R., and Amann, R. (2001). The species concept for prokaryotes. FEMS Microbiol. Rev. 25, 39-67. doi: 10.1016/S0168-6445(00)00040-1

Roussel, E. G., Sauvadet, A. L, Allard, J., Chaduteau, C., Richard, P., Cambon Bonavita, M. A., et al. (2009). Active archaeal methane cycling communities associated with gassy subsurface sediments of marennes-oléron bay (France) Science 320, 1046. doi: 10.1126/science.1154545

Schloss, P. D., and Handelsman, J. (2005). Introducing DOTUR, a computer program for defining operational taxonomic units and estimating species richness. Appl. Environ. Microbiol. 71, 1501-1506. doi: 10.1128/AEM.71.3.15011506.2005

Syutsubo, K., Sinthurat, N., Ohashi, A., and Harada, H. (2001). Population dynamics of anaerobic microbial consortia in thermophilic granular sludge in response to feed composition change. Water Sci. Technol. 43, 59-66.

Widdel, F., and Rabus, R. (2001). Anaerobic biodegradation of saturated and aromatic hydrocarbons. Curr. Opin. Biotech. 12, 259-276. doi: 10.1016/S09581669(00)00209
Wilkes, H., Vieth, A., and Elias, R. (2008). Constraints on the quantitative assessment of in-reservoir biodegradation using compound-specific stable carbon isotopes. Org. Geochem. 39, 1215-1221. doi: 10.1016/j.orggeochem.2008. 02.013

Yakimov, M. M., Denaro, R., Genovese, M., Cappello, S., D’Auria, G., Chernikova, T. N., et al. (2005). Natural microbial diversity in superficial sediments of Milazzo Harbor (Sicily) and community successions during microcosm enrichment with various hydrocarbons. Environ. Microbiol. 7, 1426-1441. doi: $10.1111 / j .1462-5822.2005 .00829 . x$

Yakimov, M. M., Giuliano, L., Denaro, R., Crisafi, E., Chernikova, T. N., Abraham, W. R., et al. (2004). Thalassolituus oleivorans gen. nov., sp. nov., a novel marine bacterium that obligately utilizes hydrocarbons. Int. J. Syst. Evol. Microbiol. 54, 141-148. doi: 10.1099/ijs.0.02424-0

Yakimov, M. M., Giuliano, L., Gentile, G., Crisafi, E., Chernikova, T. N., Abraham, W. R., et al. (2003). Oleispira antarctica gen. nov., sp. nov., a novel hydrocarbonoclastic marine bacterium isolated from Antarctic cosatal sea water. Int. J. Syst. Evol. Microbiol. 53, 779-785. doi: 10.1099/ijs.0.02366-0

Yakimov, M. M., Golyshin, P. N., Lang, S., Moore, E. R. B., Abraham, W. R., Lünsdorf, H., et al. (1998). Alcanivorax borkumensis gen. nov., sp. nov., a new, hydrocarbon-degrading and surfactant-producing marine bacterium. Int. J. Syst. Bacteriol. 48, 339-348. doi: 10.1099/00207713-48-2-339

Yakimov, M. M., Timmis, K. N., and Golyshin, P. N. (2007). Obligate oil-degrading marine bacteria. Curr. Opin. Biotech. 18, 257-266. doi: 10.1016/j.copbio.2007.04.006

Conflict of Interest Statement: The authors declare that the research was conducted in the absence of any commercial or financial relationships that could be construed as a potential conflict of interest.

Received: 02 December 2013; accepted: 25 March 2014; published online: 14 April 2014.

Citation: Genovese M, Crisafi F, Denaro R, Cappello S, Russo D, Calogero R, Santisi $S$, Catalfamo M, Modica A, Smedile F, Genovese L, Golyshin PN, Giuliano L and Yakimov MM (2014) Effective bioremediation strategy for rapid in situ cleanup of anoxic marine sediments in mesocosm oil spill simulation. Front. Microbiol. 5:162. doi: 10.3389/fmicb.2014.00162

This article was submitted to Aquatic Microbiology, a section of the journal Frontiers in Microbiology.

Copyright $\odot 2014$ Genovese, Crisafi, Denaro, Cappello, Russo, Calogero, Santisi, Catalfamo, Modica, Smedile, Genovese, Golyshin, Giuliano and Yakimov. This is an open-access article distributed under the terms of the Creative Commons Attribution License (CC BY). The use, distribution or reproduction in other forums is permitted, provided the original author(s) or licensor are credited and that the original publication in this journal is cited, in accordance with accepted academic practice. No use, distribution or reproduction is permitted which does not comply with these terms. 